University of Nebraska - Lincoln

DigitalCommons@University of Nebraska - Lincoln

2000

Nest Predation on Black-Tailed Prairie Dog Colonies

Bruce Baker

U.S. Geological Survey

Thomas R. Stanley

U.S. Geological Survey

Glenn Plumb

U.S. Geological Survey

Follow this and additional works at: https://digitalcommons.unl.edu/usgsstaffpub

Part of the Earth Sciences Commons

Baker, Bruce; Stanley, Thomas R.; and Plumb, Glenn, "Nest Predation on Black-Tailed Prairie Dog Colonies" (2000). USGS Staff -- Published Research. 50.

https://digitalcommons.unl.edu/usgsstaffpub/50

This Article is brought to you for free and open access by the US Geological Survey at DigitalCommons@University of Nebraska - Lincoln. It has been accepted for inclusion in USGS Staff -- Published Research by an authorized administrator of DigitalCommons@University of Nebraska - Lincoln. 


\title{
NEST PREDATION ON BLACK-TAILED PRAIRIE DOG COLONIES
}

BRUCE W. BAKER, ${ }^{1}$ U.S. Geological Survey, Midcontinent Ecological Science Center, 4512 McMurry Avenue, Fort Collins, CO 80525, USA

THOMAS R. STANLEY, U.S. Geological Survey, Midcontinent Ecological Science Center, 4512 McMurry Avenue, Fort Collins, CO 80525, USA

GLENN E. PLUMB, ${ }^{2}$ Badlands National Park, P.O. Box 6, Interior, SD 57750, USA

\begin{abstract}
Nest predation is the principal cause of mortality for many grassland birds. Predation rates may be higher on prairie dog colonies because they may have less available nesting cover and may increase predator abundance. We compared 14-day nest predation rates for 1,764 artificial nests on 102 black-tailed prairie dog (Cynomys ludovicianus) colonies and their paired off-colony sites (similar habitat lacking prairie dogs) from 14 May to 26 June 1998 in South Dakota and Wyoming. Predation rates on colonies $(66.2 \pm 2.2 \% ; \bar{x} \pm$ SE) were $29.5 \%$ higher than at off-colony sites $(51.1 \pm 2.7 \%)$. Nesting cover on colonies was less dense and more uniform in structure and regression analysis showed differences in nest predation rates were correlated with estimates of mean nesting cover. Avian species associated with prairie dog colonies had smaller clutches and more broods/ year than species associated with off-colony sites, suggesting a mechanism that may help compensate for increased risk of nest failure. Factors that influence predator-prey dynamics (e.g., habitat fragmentation) or foraging success (e.g., insect availability) also may help explain higher risk of nest predation on prairie dog colonies. Our conclusions support others in recommending protection of large, intact prairie dog ecosystems.
\end{abstract}

JOURNAL OF WILDLIFE MANAGEMENT 64(3):776-784

Key words: artificial nest, avian fitness, experimental nest, Cynomys leucurus, Cynomys ludovicianus, groundnesting birds, habitat fragmentation, mixed-grass prairie, shrub-steppe, South Dakota, white-tailed prairie dog, Wyoming.

Nest predation is the principal cause of nest loss for a great variety of birds (Ricklefs 1969, Martin 1993). Predation rates can be higher where nesting cover is less dense or more uni-

${ }^{1}$ E-mail: bruce_baker@usgs.gov

2 Present address: Yellowstone Center for Resources, P.O. Box 168, Yellowstone National Park, WY 82190 , USA. form in structure, or predator abundance is higher (Bowman and Harris 1980, Martin 1996). Prairie dogs (Cynomys spp.) may modify vegetation structure and increase predator abundance on colonies; ecological functions that, in part, have been used to justify their status as a keystone species (Whicker and Detling 1988, Miller et al. 1994, Kotliar et al. 1999). 

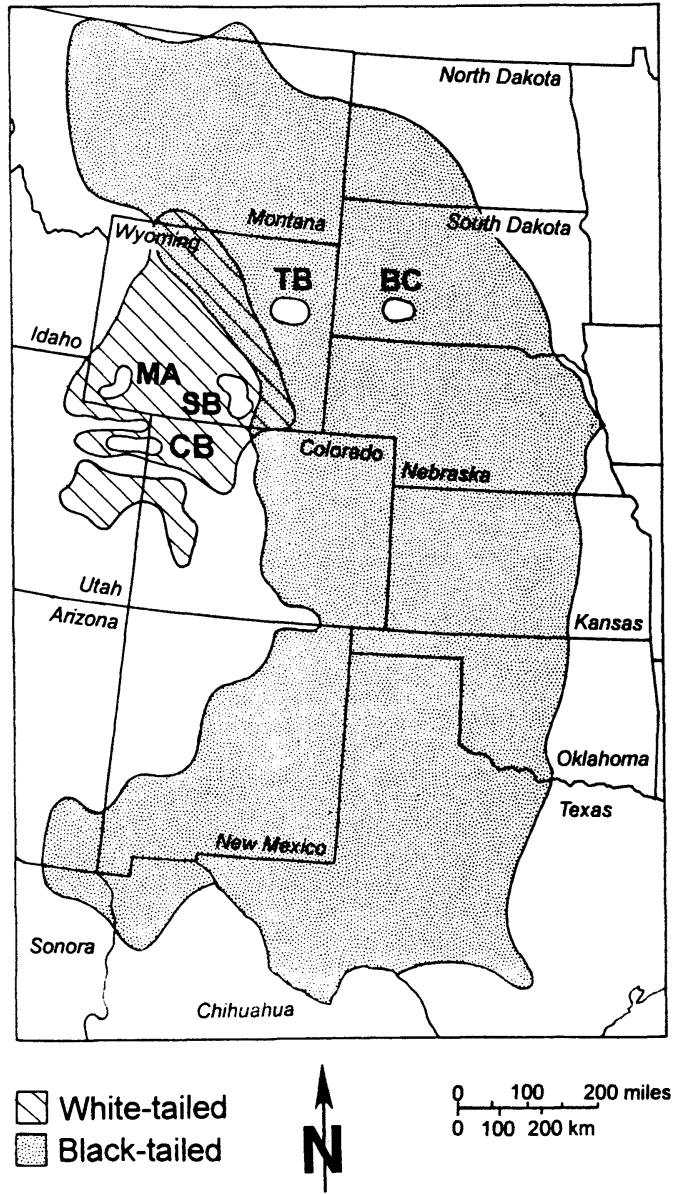

Fig. 1. Range of the black-tailed prairie dog (Cynomys /udovicianus; Hall 1981) and complexes sampled for this study (BC = Badlands-Conata, sampled 14 May-2 Jun, 1998; TB = Thunder Basin, sampled 6-26 Jun, 1998). Range of the whitetailed prairie $\operatorname{dog}(C$. leucurus) is shown for comparison; complexes were sampled by Baker et al. (1999; $C B=$ Coyote Basin, sampled 27 May-18 Jun, 1997; MA = Moxa Arch, sampled 18-29 Jun, 1997; and SB = Shirley Basin, sampled 30 Jun-16 Jul, 1997). Suitable habitat is fragmented or unoccupied in much of the depicted range for both prairie dog species, but especially for black-tailed.

Collectively, the 5 species of prairie dogs once were widespread and abundant in west-central North America (Fig. 1; Anderson et al. 1986). However, prairie dogs have been treated as agricultural pests since European settlement of the Great Plains. The range of the black-tailed prairie $\operatorname{dog}$ (C. ludovicianus) has been reduced by as much as $98 \%$ due to habitat loss from agricultural and other development, poisoning to eliminate forage competition with livestock, and sylvatic plague (Yersinia pestis; Marsh 1984, Miller et al. 1994). Prompted by continued declines, the National Wildlife Federation formal- ly petitioned the U.S. Fish and Wildlife Service to list the black-tailed prairie dog as a threatened species under the Endangered Species Act (K. Graber, T. France, and S. Miller, unpublished report). Grassland and shrub-steppe birds, including species associated with prairie dogs, also have experienced regional population declines (Kotliar et al. 1999, Knopf 1996). Many of these species, such as the mountain plover (Charadrius montanus), horned lark (Eremophila alpestris), and McCown's longspur (Calcarius mccownii), nest on the ground in prairie dog colonies where they may experience higher rates of nest predation (Baker et al. 1999).

Nest predation rates may be higher on prairie dog colonies because nests may be easier for predators to locate and predators may be more abundant. Nests on colonies may be easier to locate because vegetation typically is shorter and less dense, a result of grazing disturbance by prairie dogs (Clark 1977, Whicker and Detling 1988). Prairie dogs clip vegetation both to consume and presumably to increase visibility for predator detection (King 1955). Clipped vegetation may create a mowed effect; thus, vegetation on colonies also may be more uniform in structure and contrast sharply with the surrounding habitat, especially in fragmented systems where colonies occupy a relatively small percentage of the landscape. Studies in fragmented tall-grass prairie and western shrubsteppe have shown higher rates of nest predation in smaller fragments, near edges, and where nesting cover is less dense (Burger et al. 1994, DeLong et al. 1995, Yahner 1996). In addition, nest predators, such as coyotes (Canis latrans), badgers (Taxidea taxus), and deer mice (Peromyscus spp.), may be 3-5 times more abundant on prairie dog colonies (O'Meilia et al. 1982, Agnew et al. 1986, Krueger 1986). Thus, if the risk of nest predation is higher where nesting cover is less dense and more fragmented, and where predators are more abundant, then nest predation rates should be higher on prairie dog colonies.

Nest predation rates were $14 \%$ higher on colonies than in similar sites lacking prairie dogs (hereafter, called off-colony sites) in a study of 74 white-tailed prairie dog (C. leucurus) colonies in Colorado, Utah, and Wyoming (Baker et al. 1999). White-tailed prairie dogs tolerate taller vegetation within colonies, occur at lower densities, and occupy less fragmented landscapes (public lands) than black-tailed prairie 
Table 1. Comparisons of type of disturbance to $1,764^{\mathrm{a}} \mathrm{ex}-$ perimental nests at 102 black-tailed prairie dog colonies and paired off-colony sites in South Dakota and Wyoming, 1998.

\begin{tabular}{lrrr}
\hline \multicolumn{1}{c}{ Type of disturbance } & \multicolumn{1}{c}{ On } & \multicolumn{1}{c}{ Off } & Total \\
\hline None & 405 & 503 & 908 \\
Egg moved but intact & 78 & 47 & 125 \\
Egg gone & 126 & 59 & 185 \\
Egg crushed or broken & 280 & 266 & 546 \\
Total & 889 & 875 & 1,764 \\
\hline
\end{tabular}

${ }^{a}$ We omitted 3 nests that were flooded and 214 nests that we could not relocate.

dogs, suggesting comparisons of nest predation rates on black-tailed prairie dog colonies and off-colony sites may show even greater differences than for white-tailed prairie dogs (Baker et al. 1999).

Our objectives in this study were to compare predation rates of artificial nests placed on and off black-tailed prairie dog colonies and to suggest factors that might explain observed differences. Specifically, we determined (1) if 14-day nest predation rates were higher on prairie dog colonies than at off-colony sites, (2) if differences in nesting cover or prairie dog burrow density were good predictors of differences in nest predation rates, and (3) if type of disturbance to nests differed on and off colonies.

\section{STUDY AREA}

Within the historical range of black-tailed prairie dogs, the more northern states of South Dakota, Montana, and Wyoming contain the majority of remaining populations. We selected our study colonies from 2 major complexes (an aggregation of colonies, Biggins et al. 1993) in this region (Fig. 1). They represented the mixed-grass prairie of South Dakota and the shortgrass/sagebrush-steppe of Wyoming, which allowed us to broaden our scope of inference and compare findings with a similar study of white-tailed prairie dogs (Fig. 1; Baker et al. 1999). In addition, each of these complexes contained a minimum of 50 large active colonies.

Badlands-Conata contained portions of Badlands National Park and Buffalo Gap National Grasslands (Conata Basin) in South Dakota (Fig. 1). Common grasses were western wheatgrass (Agropyron smithii), buffalograss (Buchloe dactyloides), blue grama (Bouteloua gracilis), needleandthread (Stipa comata), and cheatgrass (Bromus tectorum). Common forbs were fetid marigold (Dyssodia papposa), scarlet globemallow (Sphaeralcea coccinea), and woolly plantain (Plantago patagonica). Pricklypear cactus (Opuntia polyacantha) was abundant. Horned larks and western meadowlarks (Sturnella neglecta) were common on prairie dog colonies; grasshopper sparrows (Ammodramus savannarum) and western meadowlarks were common at off-colony sites. Killdeer (Charadrius vocifer$u s$ ), upland sandpipers (Bartramia longicauda), and lark buntings (Calamospiza melanocorys) also were present. Sites within the complex were grazed by bison (Bison bison) or domestic cattle. Although sylvatic plague occurs in many black-tailed prairie dog populations, it has not been confirmed at Badlands-Conata. Recreational prairie dog shooting was frequent in Conata Basin, but not permitted in Badlands. In recent years, coyote populations have been reduced by aerial gunning and other means (which likely increased annual mortality relative to previous recreational shooting) to decrease

Table 2. Comparisons of 14-day nest predation rates and habitat variables at 102 black-tailed prairie dog colonies and paired off-colony sites at the Badlands-Conata complex in South Dakota and the Thunder Basin complex in Wyoming, 1998.

\begin{tabular}{|c|c|c|c|c|c|}
\hline \multirow[b]{3}{*}{ Variable } & \multirow[b]{3}{*}{ Site } & \multicolumn{4}{|c|}{ Complex } \\
\hline & & \multicolumn{2}{|c|}{$\begin{array}{c}\text { Badlands-Conata } \\
\left(n^{\mathrm{a}}=53\right)\end{array}$} & \multicolumn{2}{|c|}{$\begin{array}{l}\text { Thunder Basin } \\
(n=49)\end{array}$} \\
\hline & & $\overline{\bar{x}}$ & SE & $\bar{x}$ & $\mathrm{SE}$ \\
\hline \multirow[t]{2}{*}{14 -day nest predation rates $(\%)$} & On & 67.9 & 3.2 & 64.4 & 3.0 \\
\hline & Off & 47.6 & 4.0 & 54.9 & 3.7 \\
\hline \multirow[t]{2}{*}{ Nesting cover $(\mathrm{cm})$} & $\mathrm{On}$ & 4.2 & 0.3 & 2.5 & 0.2 \\
\hline & Off & 7.2 & 0.5 & 8.1 & 0.5 \\
\hline \multirow[t]{2}{*}{$\mathrm{SD}^{\mathrm{b}}$ of nesting cover $(\mathrm{cm})$} & $\mathrm{On}$ & 2.7 & 0.2 & 2.0 & 0.1 \\
\hline & Off & 3.3 & 0.1 & 5.9 & 0.4 \\
\hline \multirow[t]{2}{*}{ Active burrows/ha } & On & 114.0 & 8.6 & 130.0 & 6.9 \\
\hline & Off & 0.7 & 0.5 & 0.2 & 0.1 \\
\hline
\end{tabular}


risk of predation on reintroduced black-footed ferrets (Mustela nigripes). We sampled Badlands-Conata 14 May-2 June 1998.

Thunder Basin National Grassland in eastern Wyoming was typical of shortgrass/shrub-steppe prairie dog range in much of Wyoming and Montana (Fig. 1). Common grasses were western wheatgrass, cheatgrass, blue grama, and needleandthread. Common forbs were scarlet globemallow and woolly plantain. Big sagebrush (Artemisia tridentata), black greasewood (Sarcobatus vermiculatus), and fringed sagebrush (A. frigida) were the dominant shrubs, and pricklypear was abundant. Horned larks and McCown's longspurs were common on prairie dog colonies; western meadowlarks, lark buntings, and Brewer's sparrows (Spizella breweri) were common at off-colony sites. Mountain plovers, killdeer, and vesper sparrows (Pooecetes gramineus) also were present. The area was grazed by domestic cattle; sylvatic plague was present, although most colonies we sampled had escaped recent outbreaks. Recreational prairie dog shooting was frequent. We sampled Thunder Basin 6-26 June, 1998.

\section{METHODS}

\section{Experimental Design}

We sampled 102 black-tailed prairie dog colonies (unit of replication) using 1,764 artificial nests in a design that paired each colony with a nearby control (off-colony site). We assumed differences in predation rates of artificial nests placed on and off colonies were proportional to differences in predation rates of natural nests (Major and Kendal 1996). Nesting cover (visual obscurity of vegetation) and burrow density were estimated on and off colonies to help explain differences in nest predation rates.

Colonies at both complexes had recently been mapped by agency personnel via walking or driving perimeters with a Global Positioning System or a combination of aerial photographs, topographic maps, and ground-truthing. From their maps, we selected and sampled all colonies that were a minimum size of approximately $400 \times 800 \mathrm{~m}$, had prairie dogs present or fresh scat (greenish-black in color) at burrows, and had a suitable off-colony site. Paired colonies and off-colony sites typically had similar grazing management (same grazing allotment containing either domestic cattle or bison), soil type, and topography. To locate off-colony sites, we looked at coiony boundaries to observe the type of habitat prairie dogs were colonizing and then searched nearby (typically $0.5-2.0 \mathrm{~km}$ ) for similar sites lacking prairie dog colonies. If a suitable off-colony site could not be located, the colony was not sampled. Some off-colony sites contained a few scattered prairie dog burrows.

\section{Artificial Nest Data}

We placed artificial nests $(\bar{x}=9.8$ nests/colony and $\bar{x}=9.7$ nests/off-colony site for 1,981 placed nests) $100 \mathrm{~m}$ apart along a single transect line in each of the 102 selected colonies and their paired off-colony sites, generally following the methods of Baker et al. (1999). Transects began near the edge of a colony and continued through the center of prairie dog activity until $900 \mathrm{~m}$ or the opposite side was reached (transect layout reflected colony shape and locations of active burrows). At off-colony sites, we tried to mimic transect layout (direction, exposure) on paired colonies. We estimated burrow density by recording the number of active prairie dog burrows within $1.5 \mathrm{~m}$ of either side of the transect line (Biggins et al. 1993). Every $100 \mathrm{~m}$ along the line we placed a pin flag, paced $10 \mathrm{~m}$ perpendicular from the line, and located a suitable nest site within a $2-\mathrm{m}$ radius. We selected nest locations using a search image that represented likely nest sites for ground-nesting birds typical of the area (Baicich and Harrison 1997). This location was often at the base of or within a shrub, grass, or pricklypear clump. We scraped a shallow depression at each nest site and estimated nesting cover using a 1.5-m-tall Robel pole (marked in 2.5-cm increments) placed at the center of the nest scrape (Robel et al. 1970). We observed the pole from opposite directions (2 readings/nest) from $1 \mathrm{~m}$ high and $4 \mathrm{~m}$ away, recording the highest interval completely obscured by vegetation. This method blends vegetation height and density into 1 measure and is often a good predictor of available nesting cover. After removing the pole, we placed a roofing nail (head painted orange) in each nest to ensure we had found the nest scrape (not a similar natural depression) during subsequent visits. In each nest, we placed a single fresh Japanese quail (Coturnix japonica) egg on top of the nail. These eggs were cream-colored with dark specks, slightly smaller than mountain plover or killdeer eggs, but larger than horned lark or sparrow eggs (some small- 
mouthed predators are unable to break quail eggs).

We typically placed equal numbers of nests on a colony and its paired off-colony site on the same day, which ensured comparable exposure to predation across sites. After an average exposure time of 9.8 days (range $=1-14$ days), nests were checked to determine if they had been disturbed. When logistical constraints permitted, we left eggs in the nest for an average of an additional 6.6 days (range $=4-10$ days), and again checked them for disturbance. We recorded nest condition each time it was checked and used 4 categories to describe type of nest disturbance: none, egg moved but intact, egg gone, and egg crushed or broken. We did not attempt to identify specific nest predators based on appearance of eggshell fragments, believing this technique leads to misidentification problems (Baker 1978, Hernandez et al. 1997, Marini and Melo 1998, Sargeant et al. 1998). We were unable to relocate 214 nests during the study, primarily because cattle, ranchers, or prairie dog shooters had pulled our flags. We also omitted 3 flooded nests from the analysis.

\section{Statistical Procedures}

We estimated 14-day nest predation rates for artificial nests by modeling the success or failure of a nest as an independent Bernoulli trial with parameter $\pi(t)$, where $\pi(t)$ is the probability a nest survives an interval $t$ days in length ( $t$ may vary among nests). If we assume the daily survival probability of a nest is constant over $t$, we can replace $\pi(t)$ with $p^{t}$ where $p$ is the daily survival probability of the nest, giving us the probability distribution

$$
P(Y=y \mid p, t)=\left(p^{t}\right)^{y}\left(1-p^{t}\right)^{1-y},
$$

where, $y=1$ if the nest survives (i.e., it "succeeds") and $y=0$ if the nest is depredated (i.e., it "fails"). Assuming that for the $i$-th colony ( $i$ $=1, \ldots, 102)$ daily survival probabilities on colonies $\left(p_{i}\right)$ and off-colony sites $\left(c_{i}\right)$ are homogeneous (i.e., colony $\times$ site combinations are homogeneous), the likelihood function for the observed data is proportional to

$$
\left.\prod_{i=1}^{102} \prod_{t}\left(p_{i}^{t}\right)^{s_{i t}\left(1-p_{i}\right)}\right) f_{i t}\left(c_{i}^{t}\right) s_{i t}^{\prime}\left(1-c_{i}^{t}\right) f^{\prime}{ }_{i t} \text {, }
$$

where, for given $i$ and $t, s$ and $s^{\prime}$ are the number of successful nests on a colony and the off-colony site, and $f$ and $f^{\prime}$ are the number of dis- turbed nests on a colony and the off-colony site. Estimators for $p_{i}, c_{i}$, and their variances were derived using standard maximum-likelihood methods (Larsen and Marx 1986), and for a given colony $\times$ site combination, are equivalent to the estimators in Johnson (1979; Baker et al. 1999). Because closed-form solutions for these estimators do not exist, we used Newton's method to solve for the parameters (Swokowski 1988). We computed 14-day nest predation rates as $1-p_{i}{ }^{14}$ for colonies and $1-c_{i}{ }^{14}$ for off-colony sites. We selected 14 days to mimic the incubation period typical of grassland and shrub-steppe birds. Variances for 14-day predation rates were derived using the delta method (Seber 1982:7-9).

Tests for differences $(d)$ between colonies and off-colony sites for 14-day artificial nest predation rates, nesting cover, and burrow density were constructed using paired $t$-tests, where $d=y_{\text {on }}-y_{\text {off }}$ and $y$ is the variable of interest. Specifically, for the 14-day predation rate of artificial nests we tested $H_{a}: \bar{d}>0$, for nesting cover we tested $H_{a}: \bar{d}<0$, for standard deviation of nesting cover we tested $H_{a}: \bar{d}<0$, and for the number of active prairie dog burrows/ ha we tested $H_{a}: \bar{d}>0$. For all tests the null hypothesis was $H_{o}: \bar{d}=0$. One-tailed tests were used because hypotheses were specified a priori. Differences in nesting cover, standard deviation of nesting cover, and burrow density were used in a multiple regression analysis to determine whether these variables were good predictors of differences in 14-day predation rates of artificial nests between colonies and offcolony sites. Akaike's Information Criterion (AIC; Akaike 1973) was used to select the regression model best supported by the data.

\section{RESULTS}

We summarized disturbance type for 1,764 artificial nests and found eggs undisturbed (unmoved and intact) at 908 nests and disturbed at 856 nests (Table 1). More nests failed on colonies than off-colony sites for all 3 types of disturbance; a total of $54 \%$ of 889 nests failed on colonies compared to $43 \%$ of 875 nests at offcolony sites.

Comparisons showed 14-day nest predation rates were $29.5 \%$ higher $\left(t_{101}=-4.6, P<\right.$ $0.001)$ on prairie dog colonies $(66.2 \pm 2.2 \%$; $\bar{x}$ $\pm \mathrm{SE})$ than at off-colony sites $(51.1 \pm 2.7 \%)$. This pattern was similar at both complexes, but differences in predation rates were greater in 
the mixed-grass prairie complex at BadlandsConata $\left(\bar{d}=20.3 \pm 4.7 \% ; t_{52}=-4.3, P<\right.$ $0.001)$ than in the sagebrush-steppe complex at Thunder Basin $\left(\bar{d}=9.5 \pm 4.4 \% ; t_{48}=-2.2, P\right.$ $=0.018$; Table 2$)$. Nesting cover estimates were significantly lower $\left(t_{101}=-11.7, P<0.001\right)$ on colonies $(3.4 \pm 0.2 \mathrm{~cm})$ than at off-colony sites $(7.6 \pm 0.4 \mathrm{~cm})$. Standard deviation of nesting cover also was significantly lower $\left(t_{101}=-7.4\right.$, $P<0.001)$ on colonies $(2.4 \pm 0.1 \mathrm{~cm})$ than at off-colony sites $(4.5 \pm 0.3 \mathrm{~cm})$, suggesting nesting cover on colonies was more uniform in structure than at off-colony sites. Density of active prairie dog burrows was significantly higher $\left(t_{101}=21.8, P<0.001\right)$ on colonies $(121.7 \pm$ 5.6 burrows/ha) than at off-colony sites $(0.4 \pm$ 0.3 burrows/ha). Patterns were similar at both complexes, nesting cover on colonies was less dense and more uniform in structure than at off-colony sites; burrow density was greater on colonies (Table 2).

To test the influence of habitat variables on nest predation, we regressed the difference in nest predation rates on and off colonies against the differences in mean nesting cover, standard deviation of nesting cover, and burrow density. The best model, as selected by AIC (AIC = -225.972), included mean nesting cover $(P=$ $0.045)$ and standard deviation of nesting cover $(P=0.111)$; burrow density was not included.

\section{DISCUSSION}

\section{Patterns of Nest Predation}

Nest predation rates may be higher on colonies $(29.5 \%$ higher in this study) if nests are easier for predators to locate. Grazing disturbance by prairie dogs typically reduces height and canopy cover of vegetation (Whicker and Detling 1988), and higher nest predation rates are typically correlated with decreased nesting cover (29 of 36 studies; Martin 1993); our results support this pattern. We found significantly less nesting cover on prairie dog colonies and cover was a significant predictor of nest predation rates. In addition, nest predation can be higher where cover is more uniform in structure because predators that develop a more narrow search image are rewarded with higher success (Bowman and Harris 1980, Martin 1996). In our study, standard deviation of nesting cover was significantly lower on colonies and was at least weakly correlated with differences in nest predation rates. Results of this study are con- sistent with a similar study of white-tailed prairie dogs in Wyoming, Utah, and Colorado (Fig. 1 ), where nest predation rates averaged $14 \%$ higher on colonies than at off-colony sites (Baker et al. 1999). Thus, nest predation was consistently higher on colonies for both black-tailed and white-tailed prairie dogs at 5 major complexes (combined data set of 3,208 artificial nests at 176 colonies). White-tailed prairie dog colónies also had less nesting cover than offcolony sites (Robel cover; Baker et al. 1999). Re-analysis of white-tailed prairie dog data from Baker et al. (1999) also showed standard deviation of nesting cover was significantly less $\left(t_{81}\right.$ $=4.7, P<0.001)$ on colonies $(2.4 \pm 0.3 \%)$ than at off-colony sites $(4.9 \pm 0.5 \%)$. Thus, in both black-tailed and white-tailed prairie dog habitat, nesting cover was more uniform in structure where nest predation rates were higher, providing empirical evidence in support of Martin's (1996) general prediction that uniform nesting cover can increase nest predation rates.

In addition to reducing available nesting cover, prairie dog colonies may attract nest predators by creating favorable habitat or by serving as an abundant source of prey. At Badlands National Park, deer mice and northern grasshopper mice (Onychomys leucogaster) were 3 and 4 times more abundant on colonies than at offcolony sites (Agnew et al. 1986). Indeed, predation by mice and other small-mouthed predators may even have been under-represented in our study because some species or individuals of mice are unable to break quail eggs (Marini and Melo 1998). Our field observations did not suggest that prairie dogs are nest predators (Baker et al. 1999), but as prey themselves, prairie dogs may attract predators that prey on nests. Predators may be attracted to colonies specifically to search for nests (primary predation) or may find nests incidentally (secondary predation) as they hunt prairie dogs, small mammals, or insects. For example, Vickery et al. (1992) demonstrated that striped skunks (Mephitis mephitis) incidentally located and depredated grassland bird nests while searching for invertebrates. Thus, nest predation rates on colonies may be higher both because the abundance of predators is higher and because there is less available nesting cover suggesting that the interaction of predator abundance and nesting cover may be an interesting topic for further study.

These patterns of higher nest predation that 
we observed for prairie dogs in North America may occur in ecologically similar species of other regions. In Central Argentina, the plains vizcacha (Lagostomus maximus, family Chinchillidae) is a large, colonial, burrowing rodent of semiarid scrub and grasslands. Like prairie dogs, vizcachas reduce height and cover of grasses and shrubs, increase forb cover, provide habitat for associated species (e.g., burrowing owls, Athene cunicularia, nest in vizcacha burrows), and may attract nest predators (e.g., felids; Branch et al. 1996; L. C. Branch, University of Florida, personal communication). In Australia, the burrowing bettong (Bettongia lesueur, family Potoroidae) is a mid-sized, colonial (warrens) burrowing marsupial, that once was widespread and abundant throughout the arid and semiarid mainland. Like prairie dogs, bettongs suffered severe population declines following European settlement; isolated populations survive only on offshore islands (Baker and Noble 1999). Before populations declined, bettongs likely altered vegetation structure (e.g., reduced brush encroachment) and provided a locally abundant food source for predators (Noble 1997). Thus, because the risk of nest predation is higher on prairie dog colonies in North America, we predict that similar patterns may occur on vizcacha colonies in Argentina and bettong colonies in Australia.

\section{Compensation for Higher Nest Predation}

Why would birds nest on prairie dog colonies if the risk of nest predation is greater than at off-colony sites? As speculation, we offer several hypotheses that may operate independently or in combination. For some species, the cost of increased nest predation may be offset by increased foraging success. Insects important to foraging birds may be more numerous and easier to catch on colonies, especially at critical times during the nesting cycle (Olson 1985, Baker et al. 1999).

Habitat fragmentation following European settlement may have increased nest predation rates on black-tailed prairie dog colonies. Both complexes we sampled have been fragmented by poisoning, sylvatic plague, or other causes. As fragmented colonies become smaller and more isolated within the landscape they may function as predator patches (Baker et al. 1999). These unique features may attract predators from the surrounding habitat matrix and provide a more narrow and successful search im- age. Predator control may have exacerbated the effects of fragmentation by altering predator composition and abundance. In particular, eradication of wolves (Canis lupus) from the Great Plains may have increased abundance of smaller more effective nest predators. In a test of the mesopredator release hypothesis, Rogers and Caro (1998) found that songbird nest success was increased by the presence of coyotes, which apparently had suppressed populations of raccoons (Procyon lotor), a more effective nest predator. In fragmented systems, mesopredator release may combine with fragmentation effects to further increase localized nest predation rates (Crooks and Soule 1999). Thus, fragmentation and predator control may have altered predator-prey dynamics on colonies and possibly increased nest predation rates after bird species evolved associations with prairie dogs.

Finally, bird species associated with prairie dogs may compensate for greater risk of nest predation by reducing the importance of individual nests. In a comparison of nest predation and fecundity for birds in various nesting guilds (e.g., excavating, ground-nesting, shrub-nesting), Martin (1995) found that species with higher nest predation rates had smaller clutches and more broods/year. Comparisons with our data suggest this same pattern may apply to birds that nest on prairie dog colonies; mean clutch size was lower and mean number of broods/year was higher for species associated with prairie dog colonies than with off-colony sites for both black-tailed (clutch size 3.0 on, 4.4 off; broods 2.5 on, 1.6 off) and white-tailed (clutch size 2.7 on, 3.4 off; broods 2.8 on, 1.8 off) prairie dogs (Fig. 1; B. W. Baker, unpublished data). For this comparison, estimates of mean clutch size and number of broods/year were obtained from the literature and associations were based on density estimates obtained in 1996 and 1997 at the same 5 complexes sampled in this study and Baker et al. (1999). Prairie dog associates were killdeer, mountain plover, mourning dove (Zenaida macroura), horned lark, and McCown's longspur; off-colony associates were grasshopper sparrow, vesper sparrow, sage sparrow (Amphispiza belli), claycolored sparrow (Spizella pallida), Brewer's sparrow, lark bunting, and western meadowlark. Thus, comparisons from both black-tailed and white-tailed prairie dog ecosystems support Martin's (1995) prediction that species nesting where predation rates are higher have smaller 
clutches and more broods. Clearly, factors other than association with prairie dogs may explain observed fecundity differences (e.g., difference in body size), but the possibility of an evolutionary pattern developed from higher predation pressures is interesting and warrants further investigation.

\section{MANAGEMENT IMPLICATIONS}

We believe the higher rates of nest predation on prairie dog colonies should not be viewed as a license to continue the widespread eradication of prairie dog populations in North America. Rather, declines in prairie dog populations have likely contributed to parallel declines in populations of closely associated species, such as the mountain plover (Knopf 1996, Kotliar et al. 1999). If, as we speculate, fragmentation of large prairie dog complexes may contribute to higher nest predation rates on colonies, then agency and other land managers should focus their efforts on the coordinated protection of large intact prairie dog ecosystems rather than piecemeal protection of isolated colonies. This recommendation is consistent with black-footed ferret reintroduction guidelines, which incrementally value complexes by their relative area (Biggins et al. 1993). Also, the protection of large, intact complexes, especially those on public lands, is the primary focus of recommendations developed by State Wildlife Agencies in response to the 1998 petition to list the blacktailed prairie dog as a threatened species (W. Van Pelt, Arizona Game and Fish, personal communication).

\section{ACKNOWLEDGMENTS}

We are most grateful to our dedicated field research assistants M. D. Cogswell, S. A. Mehta, A. C. Rinker, J. H. Tasoff, J. D. Tjornehoj, and C. M. Wingert. We thank B. P. Bessken and W. M. Perry for providing maps of prairie dog colonies and technical support at BadlandsConata and T. Byer for similar support at Thunder Basin. J. A. Sedgwick initially suggested the idea of evaluating nest predation on prairie dog colonies and S. K. Skagen and B. Bailey offered valuable insights gained from their studies at Pawnee National Grasslands. P. Chapman of Colorado State University provided valuable advice concerning sampling design and data analysis. D. E. Biggins, F. L. Knopf, J. E. Roelle, and S. K. Skagen provided helpful discussion and manuscript review. This study was initiated through the Department of the Interior research needs process and was funded by the U.S. Geological Survey, Fort Collins, Colorado.

\section{LITERATURE CITED}

Agnew, W., D. W. URESK, AND R. M. Hansen. 1986. Flora and fauna associated with prairie dog colonies and adjacent ungrazed mixed-grass prairie in western South Dakota. Journal of Range Management 39:135-139.

AKAIKE, H. 1973. Information theory as an extension of the maximum likelihood principle. International Symposium on Information Theory 2:267-281.

Anderson, E., S. C. Forrest, T. W. Clark, and L. Richardson. 1986. Paleobiology, biogeography, and systematics of the black-footed ferret, Mustela nigripes (Audubon and Bachman), 1851. Great Basin Naturalist Memoirs 8:11-62.

BaICICH, P. J., AND C. J. O. HARRison. 1997. A guide to the nests, eggs, and nestlings of North American birds. Second edition. Academic Press, San Diego, California, USA.

BAKER, B. W. 1978. Ecological factors affecting wild turkey nest predation on South Texas rangelands. Proceedings of the Annual Conference of the Southeastern Association of Fish and Wildlife Agencies 32:126-136.

AND J. C. Noble. 1999. People, vermin and loss of biodiversity: prairie dogs in North America and burrowing bettongs in Australia. Pages 647648 in Proceedings VI International Rangeland Congress, Townsville, Australia.

- T. R. Stanley, ANd J. A. SedGWICK. 1999. Predation of artificial ground nests on whitetailed prairie dog colonies. Journal of Wildlife Management 63:270-277.

Biggins, D. E., B. J. Miller, L. R. Hanebury, B. OAKleaf, A. H. Farmer, and R. Crete. 1993. A technique for evaluating black-footed ferret habitat. Pages 73-88 in J. L. Oldemeyer, D. E. Biggins, and B. J. Miller, editors. Proceedings of the symposium on the management of prairie dog complexes for the reintroduction of the blackfooted ferret. U.S. Fish and Wildlife Service Biological Report 13.

Bowman, G. B., AND L. D. Harris. 1980. Effect of spatial heterogeneity on ground-nest depredation. Journal of Wildlife Management 44:806813.

Branch, L. C., D. Villarreal, and J. L. Hierro, AND K. M. Portier. 1996. Effects of local extinction of the plains vizcacha (Lagostomus maximus) on vegetation patterns in semi-arid scrub. Oecologia 106:389-399.

Burger, L. D., L. W. Burger, ANd J. FAaborg. 1994. Effects of prairie fragmentation on artificial nests. Journal of Wildlife Management 58:249254.

Clark, T.W. 1977. Ecology and ethology of the whitetailed prairie dog (Cynomys leucurus). Milwaukee Public Museum Publications in Biology and Geology 3.

Crooks, K. R., And M. E. Soule. 1999. Mesopre- 
dator release and avifaunal extinctions in a fragmented system. Nature 400:563-566.

Delong, A. K., J. A. Crawford, and D. C. DELONG. 1995. Relationships between vegetational structure and predation of artificial sage grouse nests. Journal of Wildlife Management 59:88-92.

HALL, E. R. 1981. The mammals of North America. Second edition. Volume 1. John Wiley \& Sons, New York, New York, USA.

Hernandez, F., D. Rollins, and R. Cantu. 1997. Evaluating evidence to identify ground-nest predators in West Texas. Wildlife Society Bulletin 25: 826-831.

JOHNSON, D. H. 1979. Estimating nest success: the Mayfield method and an alternative. Auk 96:651661 .

KING, J. A. 1955. Social behavior, social organization, and population dynamics in a black-tailed prairie dog town in the Black Hills of South Dakota. Contributions from the Laboratory of Vertebrate Biology No. 67, University of Michigan, Ann Arbor, Michigan, USA.

KNOPF, F. L. 1996. Prairie legacies-birds. Pages $135-148$ in F. B. Samson and F. L. Knopf, editors. Prairie conservation: preserving North America's most endangered ecosystem. Island Press, Washington, D.C., USA.

Kotliar, N. B., B. W. BaKer, A. D. Whicker, AND G. Plumb. 1999. A critical review of assumptions about the prairie dog as a keystone species. Environmental Management 24:177-192.

KRUEGER, K. 1986. Feeding relationships among bison, pronghorn, and prairie dogs: an experimental analysis. Ecology 67:760-770.

LARSEN R. J., AND M. L. MARX. 1986. An introduction to mathematical statistics and its applications. Second edition. Prentice-Hall, Englewood Cliffs, New Jersey, USA.

Major, R. E., AND C. E. KENDAL. 1996. The contribution of artificial nest experiments to understanding avian nest success: a review of methods and conclusions. Ibis 138:298-307.

Marini, M. A., AND C. MElo. 1998. Predators of quail eggs, and evidence of the remains: implications for nest predation studies. Condor 100: 395-399.

MARSH, R. E. 1984. Ground squirrels, prairie dogs, and marmots as pests on rangeland. Pages 195208 in Proceedings of the conference for the organization and practice of vertebrate pest control, Hampshire, England, August 30-September 3, 1982. Plant Protection Division, Fernherst, England.

MARTIN, T. E. 1993. Nest predation and nest sites: new perspectives on old patterns. Bioscience 43 : 523-532.

1995. Avian life history evolution in relation to nest sites, nest predation, and food. Ecological Monographs 65:101-127.

1996. Fitness costs of resource overlap among coexisting bird species. Nature 380:338-340.

Miller, B., G. Ceballos, and R. Reading. 1994. The prairie dog and biotic diversity. Conservation Biology 8:677-681.

Noble, J. C. 1997. The delicate and noxious scrub: CSIRO studies on native tree and shrub proliferation in the semi-arid woodlands of eastern Australia. CSIRO, National Rangelands Program, Lyneham, Australian Capitol Territory, Australia.

OLSON, S. L. 1985. Mountain plover food items on and adjacent to a prairie dog town. Prairie Naturalist 17:83-90.

O'Meilia, M. E., F. L. KNOPF, AND J. C. Lewis. 1982. Some consequences of competition between prairie dogs and beef cattle. Journal of Range Management 35:580-585.

RICKLEFS, R. E. 1969. An analysis of nesting mortality in birds. Smithsonian Contributions in Zoology 9: $1-48$.

Robel, R. J., J. N. Briggs, A. D. Dayton, AND L. C. Hulbert. 1970. Relationships between visual obstruction measurements and weight of grassland vegetation. Journal of Range Management 23:295-297.

Rogers, C. M., AND M. J. CARo. 1998. Song sparrows, top carnivores and nest predation: a test of the mesopredator release hypothesis. Oecologia 116:227-233.

Sargeant, A. B., M. A. Sovada, AND R. J. GreenWOOD. 1998. Interpreting evidence of depredation of duck nests in the prairie pothole region. U.S. Geological Survey, Northern Prairie Wildlife Research Center, Jamestown, North Dakota and Ducks Unlimited, Memphis, Tennessee, USA.

Seber, G. A. F. 1982. The estimation of animal abundance and related parameters. Second edition. Macmillan, New York, New York, USA.

SwOKOWSKI, E. W. 1988. Calculus with analytic geometry. Fourth edition. PWS-Kent Publishing, Boston, Massachusetts, USA.

ViCKeRY, P. D., M. L. Hunter, AND J. V. Wells. 1992. Evidence of incidental nest predation and its effects on nests of threatened grassland birds. Oikos 63:281-288.

Whicker, A. D., AND J. K. Detling. 1988. Ecological consequences of prairie dog disturbances. Bioscience 38:778-785.

YAHNER, R. H. 1996. Forest fragmentation, artificial nest studies, and predator abundance. Conservation Biology 10:672-673.

Received 11 October 1999.

Accepted 28 January 2000.

Associate Editor: Boutin. 